Revista Eletrônica de Direito Processual - REDP.

Rio de Janeiro. Ano 13. Volume 20. Número 1. Janeiro a Abril de 2019

Periódico Quadrimestral da Pós-Graduação Stricto Sensu em Direito Processual da UERJ

Patrono: José Carlos Barbosa Moreira (in mem.). ISSN 1982-7636. pp. 288-314

www.redp.uerj.br

\title{
MOMENTOS ENTRE O PASSADO E O PRESENTE DO PROCESSO PENAL NO CONTEXTO DO SISTEMA CRIMINAL ${ }^{1}$
}

\section{HISTORICAL MOMENTS OF CRIMINAL SYSTEM}

\section{Luis Gustavo Grandinetti Castanho de Carvalho} Pós doutor pela Universidade de Coimbra. Doutor pela UERJ. Mestre pela PUC-RJ. Graduado pela UERJ. Professor Adjunto da UERJ. Rio de Janeiro/RJ. E-mail: gustavograndine@gmail.com

RESUMO: O artigo se propõe a pesquisar momentos históricos que marcaram o processo penal e o processo penal brasileiro para analisar quais tendências conformarão a atuação da justiça criminal no Brasil, no início do século XXI.

PALAVRAS-CHAVE: história do processo penal, justiça criminal, sistema criminal, juiz criminal.

ABSTRACT: This paper will research some historical moments of the criminal system and the trends that will shape the performance of criminal system, in Brazil, in the beggining of XXI century.

KEYWORDS: history of the criminal system, criminal justice, criminal judge.

SUMÁRIO: 1. Introdução; 2. Escorço Histórico do Processo Criminal; 3. Tendências para o Sistema Criminal no Início do Século XXI no Brasil; 4. Conclusão.

SUMMARY: 1. Introducción; 2. Historical Foreshortening of Criminal Justice; 3. Trends for Criminal System in the Beggining of XXI Century in Brazil; 4. Conclusion.

\footnotetext{
${ }^{1}$ Artigo recebido em 18/12/2018 e aprovado em 30/03/2019.
} 
Revista Eletrônica de Direito Processual - REDP.

Rio de Janeiro. Ano 13. Volume 20. Número 1. Janeiro a Abril de 2019

Periódico Quadrimestral da Pós-Graduação Stricto Sensu em Direito Processual da UERJ

Patrono: José Carlos Barbosa Moreira (in mem.). ISSN 1982-7636. pp. 288-314

www.redp.uerj.br

1.Introdução

É sempre um grande desafio perscrutar o futuro em qualquer atividade. O desafio ainda é maior quando se trata de fazê-lo no que concerne às instituições públicas, entidades complexas nas quais convergem tendências políticas e sociais que se movem no cenário da evolução histórica, sempre algo imprevisível.

Apesar das dificuldades inerentes e dos riscos evidentes, uma metodologia que pode conferir um pouco mais de segurança à trajetória é o exame dessas mesmas instituições no passado, pois foram construídas para alcançarem determinados fins estabelecidos pelas sociedades respectivas. Parodiando o que Hegel afirmou sobre os indivíduos - cada um é filho do seu tempo ${ }^{2}$ - as sociedades também são tributárias de um longo processo histórico, pelo qual se pode compreender certas tendências de evolução ou de involução.

São essas tendências reveladoras do que o autor chamou de caráter de um povo e de uma época ${ }^{3}$. Compreender esse caráter, de um povo e de uma época, pode fornecer certas pistas pelas quais se pode projetar tendências para o futuro, ainda que sejam, simplesmente, tendências, que não venham a se concretizar.

O problema que se impõe é examinar se o desenvolvimento histórico do direito processual penal foi influenciado pelos momentos históricos e pelos movimentos políticos que se seguiram, bem como se a demanda por segurança, ordem e disciplina é cíclica e se ela influi no sistema processual penal. $\mathrm{O}$ artigo propõe-se examinar, como hipóteses, se há coincidência desses momentos históricos que impõem maior demanda por segurança, ordem e disciplina e a perda de democraticidade processual, ou se não há influência entre os dois campos, o histórico e o processual penal.

Assim, o objetivo do trabalho será mergulhar na história do processo penal, a partir do marco que representou o direito romano, escolhido por exercer, ainda hoje, forte influência no direito europeu e no direito processual brasileiro, de modo a tornar possível chegar-se ao sistema processual penal brasileiro do presente século. Começar-se-á a pesquisa

\footnotetext{
${ }^{2}$ HEGEL, Georg Wilhem Friedrich. Princípios da Filosofia do Direito. Lisboa: Guimarães e Cia Editores, $2^{\mathrm{a}}$ edição, 1976, p. 14. O trecho referido é o seguinte: "A missão da filosofia está em conceber o que é, porque o que é, é a razão. No que se refere aos indivíduos, cada um é filho do seu tempo; assim também para a filosofia que, no pensamento, pensa o seu tempo".

${ }^{3}$ Ibidem, p. 21.
} 
Revista Eletrônica de Direito Processual - REDP.

Rio de Janeiro. Ano 13. Volume 20. Número 1. Janeiro a Abril de 2019

Periódico Quadrimestral da Pós-Graduação Stricto Sensu em Direito Processual da UERJ

Patrono: José Carlos Barbosa Moreira (in mem.). ISSN 1982-7636. pp. 288-314

www.redp.uerj.br

em Roma para chegar-se ao Brasil dos dias atuais. O estudo dessa trajetória, que não se pretende de um rigor linear, contudo, não se limitará ao aspecto puramente processual, mas, também, à ambiência política de cada momento histórico, que certamente marcou o funcionamento da justiça criminal, bem como será necessário construir algumas pontes outros saberes do direito e fora dele também.

O exame retrospectivo da história do processo penal permitirá contemplar a hipótese de que o direito processual penal integre uma concepção mais ampla, comprometida com uma noção integral, já denominada de fenomenologia da justiça penal ${ }^{4}$, que incorpore a história do direito, o direito processual penal e o direito penal, além da ciência política e da criminologia, de modo a compreender a realidade complexa e completa do fenômeno jurídico criminal. A partir daí, será possível tratar de um sistema criminal.

Seguindo Canaris ${ }^{5}$, um sistema visa a duas tarefas primordiais: contribui para a plena composição do conteúdo teleológico de uma norma ou de um instituto jurídico; e serve para a garantia e a realização da adequação valorativa e de unidade interior do Direito. $\mathrm{O}$ conteúdo teleológico visa a revelar os valores fundamentais mais profundos assentados nos princípios gerais de uma ordem jurídica, de modo a circunscrever a adequação valorativa das normas e institutos a esse conteúdo, numa unidade do Direito ${ }^{6}$. Cumpre esclarecer, com o mesmo autor, que não se trata de um sistema fechado, mas aberto, diante do reconhecimento de que é da essência do Direito ser um fenômeno histórico ${ }^{7}$.

Estamos, contudo, num caminho de incertezas, muito árido, portanto, para que se possa reivindicar o rigor científico. A proposta científica seria modesta, a de reconhecer essas tantas tendências e incertezas contemporâneas, para arriscar-nos em um prognóstico, ainda que seja contra as advertências de Hegel: "tão grande loucura é imaginar que uma filosofia ultrapassará o mundo contemporâneo",

Vamos, então, tentar dar conta dessa tarefa, consciente dos riscos inerentes.

\footnotetext{
${ }^{4}$ A expressão é de MARIO SBRICCOLI (Cfr MARAFIOTI, Luca - Caleidoscopio dello Storico ed Occhili del Processualpenalista, in Rivista di Diritto Processuale, p. 365-374).

${ }^{5}$ CANARIS, Claus-Wilhem. Pensamento Sistemático e Conceito de Sistema na Ciência do Direito. 3 ed. Lisboa: Fundação Calouste Gulbenkian, 2002, p. 283.

${ }^{6}$ Ibidem, p. 77-78.

${ }^{7}$ Ibidem, p. 281.

${ }^{8}$ Ibidem, p. 14. A advertência é complementada por uma ameaça contundente: "Se uma teoria ultrapassar esses limites, se construir um mundo tal como entenda dever ser, este mundo existe decerto, mas apenas na opinião que é um elemento inconsciente sempre pronto a adaptar-se a qualquer forma".
} 
Revista Eletrônica de Direito Processual - REDP.

Rio de Janeiro. Ano 13. Volume 20. Número 1. Janeiro a Abril de 2019

Periódico Quadrimestral da Pós-Graduação Stricto Sensu em Direito Processual da UERJ

Patrono: José Carlos Barbosa Moreira (in mem.). ISSN 1982-7636. pp. 288-314

www.redp.uerj.br

\section{Escorço Histórico do Processo Penal: da Europa Continental para o Brasil}

Por razões metodológica e histórica, cumpre estabelecer um limite a esse pretendido escorço histórico. Por ambas as razões, se constata que não haverá valia em buscar uma retrospectiva que abranja o direito da common law porque a nossa tradição processual penal remonta aos países de civil law, ainda que se reconheça méritos no processo penal daquele ramo do direito, especialmente o processo penal do Reino Unido 9 .

Para o nosso objetivo, há que se partir de Roma, da Realeza até 509 a. C., fase em que a ideia de justiça era dominada por elementos místicos. Não havia propriamente um ius dicere porque não havia, propriamente, um julgamento. Ao ato supostamente criminoso, passava-se logo à aplicação da pena. Se se tratasse de um ato que violasse valores sagrados, como, por exemplo, o incesto de vestais ${ }^{10}$, passava-se logo à punição para aplacar a ira dos deuses contra a comunidade toda e não somente contra o criminoso. Se o ato supostamente criminoso violasse valores individuais, como o furto, o dano, etc, passava-se logo à vingança por parte da família da vítima. Não havia acusação oficial e o juiz apenas observava a regularidade formal para encaminhar a aplicação da pena ${ }^{11}$.

\footnotetext{
${ }^{9} \mathrm{O}$ processo penal inglês está caracterizado pela instituição do júri e pelo sistema adversarial. No século XII, a Inglaterra ainda estava sob a influência da Igreja e dos juízos de Deus, que, no século seguinte, proibiria estes últimos, no Concílio de Latrão, em 1215. O júri já existia, mas, inicialmente, para investigar infrações fiscais (franquish inquest). Depois, como faculdade do réu (para fugir do brutal sistema tradicional). Em Clarendon, em 1166 substitui-se a acusação particular pelo indictment, como a voz do povo, formalizada pelo juiz de fora. Com a proibição dos juízos de deus, o júri passou a julgar crimes, acumulando a investigação e o julgamento. Em 1350, Eduardo III, autorizou a recusa de jurados que tinham participado da investigação, dando origem a bipartição do júri em grand jury e petty jury. O réu, nesse período, não tinha direito à defesa técnica. A prisão era a regra e ocorria em condições sub-humanas. O júri era formado pelo juiz da coroa, escolhido pelo rei, e 12 jurados escolhidos pelo primeiro, cabendo ao juiz a função precípua de regular o julgamento, podendo, para tanto, excluir provas. Em 1608, Edward Coke recusa a ingerência do rei nos julgamentos, dando origem ao princípio do juiz natural. Em crimes contra a coroa, havia um procurador da coroa. Nos demais, a sociedade podia se constituir em associações voltadas à persecução penal. Em 1730, admite-se a defesa técnica, embora limitada a assessorar. Desse modo, ao longo de alguns séculos, foi-se desenhando um sistema adversarial, caracterizado por: neutral decision maker, party control, highly structered forensic setting e exclusionary rules. Basicamente, com poder dispositivo das partes no que toca à prova e ônus da prova para o acusador. $\mathrm{O}$ acusado só é inquirido se o desejar (COUTINHO, Jacinto Nelson de Miranda O Papel do Novo Juiz no Processo Penal, p. 3-55, in COUTINHO, Jacinto Nelson de Miranda. Crítica à Teoria Geral do Direito Processual Penal. Rio de Janeiro: Renovar, 2001; CORDERO, Franco. Guida alla Procedura Penale. Turim: Unione Tipografico Editrice Torinese, 1986; e MALAN, Diogo. Direito ao Confronto no Processo Penal. Rio de Janeiro: Lumen Juris, 2009).

${ }^{10}$ As vestais eram virgens que guardavam os templos à Deusa Vesta, que deveria existir em todos os lares romanos.

11 GIOFFREDI, Carlo. Diritto e Processo Nelle Antiche Forme Giuridiche Romane. Roma: Romae Appolinaris, 1955.
} 
Revista Eletrônica de Direito Processual - REDP.

Rio de Janeiro. Ano 13. Volume 20. Número 1. Janeiro a Abril de 2019

Periódico Quadrimestral da Pós-Graduação Stricto Sensu em Direito Processual da UERJ

Patrono: José Carlos Barbosa Moreira (in mem.). ISSN 1982-7636. pp. 288-314

www.redp.uerj.br

Na República Romana, de 509 até 27 a. C. havia, sim, um sistema de direito

(Lei das XII Táboas, 450 a. C.) e de justiça, inspirado na cultura helenística. Já se compreendia a diferença entre processo privado e processo público, entre delitos privados e delitos públicos. O processo público se destinava ao julgamento dos delitos públicos (contra o estado), em que a pena era pública; e dos delitos privados (furto, roubo, injúria, dano etc), em que a pena era privada, cumulada com o ressarcimento. O processo público era movido por uma acusação particular, nos delitos privados, e pela acusação popular, nos delitos públicos, submetidas a um julgamento popular, de natureza comicial, que haveria de produzir uma decisão irretratável. Nesse julgamento público vinha a nota essencial do processo romano: publicidade, contraditório e igualdade das partes, ao ponto de garantir-se preferencialmente a liberdade do acusado ${ }^{12}$ para que ficasse em posição de igualdade em relação ao acusador e para que pudesse levar as suas provas ao tribunal. O ônus da prova era do acusador, com algumas poucas regras de exclusão de prova (o depoimento de uma testemunha só, bem como a confissão e determinadas pessoas que não podiam testemunhar). Para limitar qualquer arbítrio do juiz na condução do julgamento era cabível a provocatio ad populum, mas, apenas, para os cidadãos romanos ${ }^{13}$.

A jurisdição, no processo privado, era prestada em duas fases: in iure, perante o pretor, juiz oficial; e in iudicium, perante um juiz escolhido pelas partes. Assumia importância a litiscontestatio, que era entendida como uma novação: substituía-se o direito originário pelo compromisso de submissão à sentença, daí vindo a noção de processo como um contrato.

Esse modelo processual foi sendo amadurecido e resultou no sistema acusatório e adversarial, inspirado no termo grego eris, que, em latim, significa contesa, em português, contenda, do qual se extrai a noção de contraditório, que foi implantado e imperou na Roma Republicana, nos séculos II e I antes de Cristo $^{14}$.

Na mesma medida em que a sociedade romana foi se degenerando este sistema processual também se degenerou: o tribunal romano, formado por jurados, era governado

\footnotetext{
${ }^{12}$ A prisão era exceção, mas podia ocorrer na forma de custodia libera em que o acusado ficava acautelado na casa de um outro cidadão romano que se responsabilizava por ele. Ou era substituída por uma espécie de prestação de fiança.

${ }^{13}$ Tratava-se de um recurso ao povo para rever os atos judiciais. Não se sabe como funcionava nos tempos da realeza, pois os registros não fornecem informações suficientes.

${ }^{14}$ TUCCI, José Rogério Cruz e. Contribuição ao Estudo Histórico do Direito Processual Penal. 1 ed. Rio de Janeiro: Forense, 1983. p. 12.
} 
Revista Eletrônica de Direito Processual - REDP.

Rio de Janeiro. Ano 13. Volume 20. Número 1. Janeiro a Abril de 2019

Periódico Quadrimestral da Pós-Graduação Stricto Sensu em Direito Processual da UERJ

Patrono: José Carlos Barbosa Moreira (in mem.). ISSN 1982-7636. pp. 288-314

www.redp.uerj.br

pela nobreza senatória ou por comerciantes, ou pelas duas classes em condomínio. Suas decisões dependiam mais dos partidos políticos do que do que se provava nos julgamentos. $\mathrm{Na}$ descrição de Cordero $^{15}$, o debate judicial mais parecia um discurso eleitoral, una inflazione fonetica, constituindo, segundo ele, uma máquina de alto rendimento onde contava muito pouco o dado técnico. Ainda: as supostas garantias do sistema acusatório, como o recurso ao julgamento popular, só valiam para cidadãos romanos homens, ficando excluídas as mulheres romanas, bem como os estrangeiros ${ }^{16}$. Até os elogiados atributos garantísticos desse sistema não vigoraram sempre, pois em alguns períodos históricos foram suprimidos: em meio à luta política envolvendo o Senado, este suspendeu as garantias e, com isso, permitiu a condenação à morte dos inimigos, sem processo, sob o consulado de Cícero (63 a. C.) e também de Brutus (178 a. C.) ${ }^{17}$.

Durante o Império Romano (27 a. C. a 476 d. C.), houve uma sensível modificação no sistema processual romano, com a instauração do processo público extraordinário, que vai se tornando a regra, que continha uma fase prévia, inquisitória, secreta, que admitia a gestão da prova por parte do juiz (prefeito ou o presidente de província). A investigação e a acusação eram entregues ao pretor, juiz oficial, que também julgava. A provocatio ad populum passa a ser dirigida ao imperador e, não mais, ao povo. A prisão passa a ser a regra, especialmente para os plebeus: in carcelum por até um ano - em cadeias públicas em crimes graves; milite traditio - o acusado ficava sob a custódia de um ou vários soldados, geralmente anciãos, que podiam até viver na casa do acusado, ou somente segui-lo; custodia libera - o acusado ficava sob custódia de alguém num castelo ou na cidade (as duas últimas somente para os nobres). Depois dessa fase prévia, voltava-se ao rito parcialmente acusatório, com produção de provas e debates em público, mas, ao final, a prolação da sentença era proferida monocraticamente ${ }^{18}$. Era possível a utilização da tortura, o recurso a delatores e a translatio, espécie de transação penal que permitia a aplicação de pena mais branda em caso de confissão.

\footnotetext{
${ }^{15}$ CORDERO, op. cit., p. 31.

${ }^{16}$ PUGLIESE, Giovanni. As Garantias do Acusado na História do Processo Penal Romano, in TUCCI, José Rogério Cruz e. Contribuição ao Estudo Histórico do Direito Processual Penal. 1 ed. Rio de Janeiro: Forense, 1983. p. 43-65 e PAGANO, Francesco Mario. Considerazioni sul Processo Criminale. Bolonha: Società Editrice Il Molino, 2010, p. 70.

${ }^{17}$ PUGLIESE, op. cit., p. 53-54.

${ }^{18}$ PAGANO, op. cit., p. 69-73. O autor assim se expressa sobre a diferença entre os dois regimes, no que diz respeito à prolatação da sentença: "Sopratutto agitandosi $i$ nuovi giudizi, non come prima nella pubblica piazza, alla vista d'un licenzioso popolo, ma tra le private mura nell'imponente solitudine” (p. 73).
} 
Revista Eletrônica de Direito Processual - REDP.

Rio de Janeiro. Ano 13. Volume 20. Número 1. Janeiro a Abril de 2019

Periódico Quadrimestral da Pós-Graduação Stricto Sensu em Direito Processual da UERJ

Patrono: José Carlos Barbosa Moreira (in mem.). ISSN 1982-7636. pp. 288-314

www.redp.uerj.br

Na Alta Idade Média, de 476 d. C até Século XI, com a queda do Império

Romano, prevalece o direito dos povos germânicos, que eram nômades, tribais, que adotavam direitos consuetudinários e vários sistemas de justiça, sob o princípio da nacionalidade. Os sistemas de direito e de justiça eram incipientes. A acusação era particular, submetida aos juízos de deus, ordálias e duelos, na qual a prova assumia um simbolismo litúrgico $^{19}$. Ainda que pudesse tratar-se de um juiz oficial, era tão somente um juiz espectador das formalidades do procedimento que possibilitava os duelos e as ordálias. Lembra Cordero ${ }^{20}$ que, nos duelos, os contendores não lutavam contra si, propriamente, mas contra um deus, na medida em que faziam o seguinte juramento: invoco o teu testemunho $e$ me submeto a tua vingança se não falo a verdade. O adversário não tinha de provar o contrário do que o outro alegava. Tudo dependia do destino, guiado pelos deuses. Nas ordálias, os contendores eram resignados. Submetiam-se a uma prova (andar sobre cinzas, ferro em brasa, água fervente) em que tudo lhes era desfavorável, aguardando um milagre. O acusado era que tinha que provar a inocência. Os julgamentos tinham lugar em assembleias e se resumiam em um espetáculo de um ato só. O juiz apenas zelava pela regularidade formal. Nesse cenário de um ato só, a prisão provisória e o sistema recursal se tornavam absolutamente desnecessários, bem como não havia qualquer preocupação com a reconstituição do fato que se estava julgando, ou com qualquer critério de verdade.

Na Baixa Idade Média, do século XI até 1453, houve uma grande transformação na Europa Continental. A economia se intensificou com o comércio e os mercados; as cidades floresceram; e o sistema feudal foi se afirmando. Essa nova matriz econômica e social carecia de uma nova ordem e de disciplina. Os senhores feudais e as monarquias que surgiam dispunham de exército, mas não de ordem. Por seu turno, a Igreja Católica dispunha de ordem, de um sistema legal e judiciário complexos, mas não tinha exército, do qual necessitava para combater os muçulmanos que invadiam a Europa e já se estendiam até Portugal. Tudo isso contribuiu para a associação entre a Igreja e as Monarquias.

Para que isso tenha sido possível, foi preciso inverter a lógica cristã originária, forte na crença de um Deus bondoso, na inclusão dos excluídos, no universalismo e na

${ }^{19}$ CORDERO, Franco. Guida alla Procedura Penale. Turim: Unione Tipografico Editrice Torinense. v. I. 1986. p. 37-43

${ }^{20}$ Op. cit. 
Revista Eletrônica de Direito Processual - REDP.

Rio de Janeiro. Ano 13. Volume 20. Número 1. Janeiro a Abril de 2019

Periódico Quadrimestral da Pós-Graduação Stricto Sensu em Direito Processual da UERJ

Patrono: José Carlos Barbosa Moreira (in mem.). ISSN 1982-7636. pp. 288-314

www.redp.uerj.br

solidariedade. Premida pelo islamismo, a religião cristã carecia ser mais agressiva e expansiva. Deus não podia ser bondoso sempre, podia perdoar, mas devia castigar o pecador; não podia aprovar o descumprimento da lei terrena. A partir de Santo Anselmo, Arcebispo de Canterbury (1033-1109), apontado por Dussel ${ }^{21}$ como o grande artífice desta transformação, a lei passa a ser o critério último de moralidade e seu descumprimento é considerado um pecado, que deve ser castigado. Aqui nasce um Deus castigador ${ }^{22}$, ao lado do pai dadivoso ${ }^{23}$. A salvação só é possível pelo cumprimento estrito da lei, todas elas: do império e da Igreja, e sob a promessa de uma vida eterna no paraíso.

Se na Antiguidade e em parte da Idade Média o imaginário da justiça se associou às forças da natureza, agora passou a adquirir simbolismo religioso, impregnandose das noções de pecado, de culpa, de impureza, que impunha exorcizar o grupo social, mediante a "desvalorização do estatuto social do acusado" que era como que "esmagado pelo cerimonial", 24 .

Substituiu-se o modelo de justiça então vigorante por uma justiça mais oficial, associada ao Estado feudal ${ }^{25}$. Nesse período, segundo Foucault, a justiça passa a "ser um conjunto de instituições estáveis, específicas, intervindo de maneira autoritária e dependente do poder público (ou controlado por ele)", concluindo, o autor, que naquele tempo de feudalismo, a justiça era fonte de riquezas para o senhor feudal ${ }^{26}$. Para dar-lhe credibilidade, era preciso associá-la aos deuses e adquirir um simbolismo religioso ${ }^{27}$.

\footnotetext{
${ }^{21}$ DUSSEL, Enrique - Política de La Liberación - História Mundial e Crítica. Madri: Editorial Trotta, 2007. 22 SANTO ANSELMO dizia que Deus é justo quando castigava os maus, pois o "Senhor é justo em todos os caminhos", tanto ao castigar, pois os maus merecem o castigo, como ao perdoar. Para aqueles que não crêem em Deus, a providência reserva infelicidade, pena e privação eternas (Monológio, Os Pensadores, p. 93/115, 1973, Abril Cultural, SP).

${ }^{23}$ Nesse ponto, comenta Dussel: “Cuando la víctima inocente, Jeshúa, es asesinada por el sistema que exige um 'rescate' (injusto) para liberar el pueblo de la estructura de dominación, el sistema manifiesta su injusticia, es la revelación de Jeshúa que se cumple en la práxis de su morte empírica. Las maquinaciónes del sistema quedan a la luz. La ley es la normatividad del orden de dominación que se manifiesta como dominación pura. Pierde su normatividad, es pura coerción externa” (op. cit, p. 103).

${ }^{24}$ GARAPON, Antoine - Bem Julgar - Ensaio sobre o Ritual Judiciário, p. 110 e 113, Instituto Piaget, Lisboa.

25 Paolo Grossi sustenta, porém, que o período medieval se caracterizava como um poder político não consumado e, assim, sem a pretensão de dominar todo fenômeno social. Consequentemente, o direito e a justiça nasceriam nem como fruto da vontade do soberano, nem como fruto da vontade geral, "mas como uma realidade historicamente e logicamente antecedente, que nasce das vastas espirais do social”. E conclui o autor: "antes existia o direito; o poder politico vem depois" (GROSSI, Paolo. Mitologias Jurídicas da Modernidade. Florianopolis: Fundação Boiteaux, 2004. p. 28-31).

${ }^{26}$ FOUCAULT, Michel. Microfísica do Poder. 8 ed. Rio de Janeiro: Ed. Graal, 1989.

${ }^{27}$ GARAPON, Antoine. Bem Julgar - Ensaio sobre o Ritual Judiciário. Lisboa: Instituto Piaget.
} 
Revista Eletrônica de Direito Processual - REDP.

Rio de Janeiro. Ano 13. Volume 20. Número 1. Janeiro a Abril de 2019

Periódico Quadrimestral da Pós-Graduação Stricto Sensu em Direito Processual da UERJ

Patrono: José Carlos Barbosa Moreira (in mem.). ISSN 1982-7636. pp. 288-314

www.redp.uerj.br

No plano processual, a contribuição deste desvirtuamento do Cristianismo se

deu com a Santa Inquisição e com o processo inquisitivo caracterizado como um procedimento em que o juiz procede de ofício à colheita da prova, acumulando as funções de julgar e de acusar, a instrução é escrita, secreta e sem direito ao contraditório, o que limitava sobremaneira a atuação da defesa. Nesse modelo, a acusação era pública, assumida pelo juiz inquisidor, que detinha, integralmente, a gestão da prova. A prisão provisória era a regra. As penas eram cruéis.

Os concílios da Igreja e as bulas papais proibiram os duelos e as ordálias e institucionalizaram esse modelo inquisitivo. Introduziu-se a tortura, de acusados e de testemunhas, na crença de que o acusado é quem detém a verdade histórica, bastando que o inquisidor penetre em sua consciência, já que trabalha no seu interesse ${ }^{28}$. Alguns criminólogos chegam a dizer que essa teorização consistiu na primeiro modelo integrado de criminologia, política criminal, direito penal e processo penal ${ }^{29}$, centrada que foi na pessoa do acusado como fonte da verdade.

Seguem-se, assim, os documentos eclesiásticos que moldaram o processo inquisitivo:

- Concílio de Verona (1184): em Verona, o Imperador Frederico Barbaroxa ${ }^{30}$ e o Papa Lúcio III delegam aos bispos investigar crimes dos albigenses.

- Bula Vergentis in Senior (1199): O papado de Inocêncio III é marcado pelo militarismo e pelas Cruzadas. Equipara-se a heresia ao crime de lesa majestade.

- Concílio de Latrão (1215): reafirma o de Verona. Considera desnecessária a acusação formal e supervaloriza os indícios.

- 1231: O Imperador Frederico $\mathrm{II}^{31}$ faz uma tentativa para retomar a repressão, agora aos cátaros, o que provoca a reação do Papa Gregório IX, que cria o Tribunal da Inquisição e nomeia inquisidores.

\footnotetext{
${ }^{28}$ CORDERO, op. cit.

${ }^{29}$ BATISTA, Vera Malaguti. Introdução Crítica à Criminologia Brasileira. Rio de Janeiro: Ed. Revan, pg. 31, 2011.

${ }^{30}$ Frederico Barbaroxa, ou Frederico I, governou o Sacro Império Romano-Germânico, desde o falecimento de seu pai, Frederico II de Suábia, em 1147, até sua abdicação em favor de seu filho Frederico V. Morreu em 1190, afogado, quando caiu de seu cavalo numa praia, após uma cruzada militar. Foi também imperador da Itália, sendo coroado como Frederico I.

${ }^{31}$ Frederico II (1194 a 1250), filho de Henrique VI, assumiu o trono da Sić́lia após a morte deste, ainda menor de idade, ficando sob regência da mãe e do Papa Inocêncio III. Somente em 1220 foi coroado imperador do Sacro-Império Romano-Germânico. Seu governo, contudo, foi repleto de atritos com a Igreja, chegando a ser excomungado.
} 
Revista Eletrônica de Direito Processual - REDP.

Rio de Janeiro. Ano 13. Volume 20. Número 1. Janeiro a Abril de 2019

Periódico Quadrimestral da Pós-Graduação Stricto Sensu em Direito Processual da UERJ

Patrono: José Carlos Barbosa Moreira (in mem.). ISSN 1982-7636. pp. 288-314

www.redp.uerj.br

- Bula ad extirpanda (1252): Inocêncio IV institucionaliza a tortura como fonte de prova (o que vai permanecer por cinco séculos). Não há contraditório, nem oralidade, nem o actio trium personarum, nem publicidade.

Por isso que o processo revelava - e o processo criminal atual ainda revela o sistema de mácula, da purgação do pecado pela culpa, como conclui Garapon ${ }^{32}$.

No âmbito da prova, passa-se a adotar a prova tarifada com base em regras de experiência, refletindo valores feudais, como fator de correção do sistema inquisitivo.

Para além da justiça criminal, o direito medieval não se caracterizou por ser onicompreensivo. O direito não era a voz do poder, porque surgia das relações comerciais, familiares, comunitárias e não esperava o poder real.

Lentamente, por obra dos glosadores (XII/XIII) e dos pós-glosadores (XIV/XV), o direito romano foi sendo recepcionado e aplicado às questões atuais, formando o Direito comum.

Os séculos XVI e XVII foram riquíssimos em todos os setores do conhecimento humano, alavancados pelo progresso das ciências exatas, pelas obras de Descartes, Bacon, Newton e Galileu, que influenciaram todos os saberes e prepararam o caminho para a grande revolução política, social e jurídica que ocorreria no século seguinte. Contudo, foram poucas as transformações no âmbito do Direito e especialmente no sistema criminal que continuou impregnado pelo sistema inquisitivo.

De relevante apenas, no plano processual, foi a adoção de um critério aritmético para a prova tarifada, diferentemente dos valores feudais do período anterior. Daí veio o estabelecimento de uma tabela para avaliar a prova, de modo que o juiz foi se transformando numa máquina calculadora. Por exemplo, o depoimento de um barão equivalia ao depoimento de 16 burgueses.

O período foi marcado pelo fortalecimento do poder central, graças, sobretudo, à teoria da soberania de Jean Bodin: um poder absoluto que também vincula as leis civis, conquanto submetido às leis divinas e morais. Nessa concepção, o poder ainda

\footnotetext{
32 “O processo conserva vestígios do sistema de mácula. O simbolismo actual do processo guarda a memória dessas etapas históricas cujo sentido está desactivado, mas que continuam a fomentar o conteúdo latente da justiça moderna. Esse sentido latente do processo deve suscitar uma vigilância constante por parte da democracia, de tal forma que existe a expulsão do impuro, do bode expiatório, na justiça moderna" (Op. cit., p. 191).
} 
Revista Eletrônica de Direito Processual - REDP.

Rio de Janeiro. Ano 13. Volume 20. Número 1. Janeiro a Abril de 2019

Periódico Quadrimestral da Pós-Graduação Stricto Sensu em Direito Processual da UERJ

Patrono: José Carlos Barbosa Moreira (in mem.). ISSN 1982-7636. pp. 288-314

www.redp.uerj.br

pertence à ordem das coisas e de Deus, porque foi dado ao mundo desde a criação e integra uma ordem eterna ${ }^{33}$. Os súditos devem jurar fidelidade à lei e ao soberano porque se a justiça é o fim da lei e a lei é a obra do Príncipe, o Príncipe é a imagem de Deus ${ }^{34}$. O Direito segue somente limitável pela equidade e pelo direito natural. Salvo o conceito abrangente de soberania, não há grande ruptura com a ordem, nem com a jurisdição, medievais.

Na transição para o século XVII, mantém-se a noção de poder como atributo da ordem divina, mas sobreleva a importância do direito natural por ser produto da razão e da sociabilidade do homem, e que produz o estado e o poder (Pufendorf) ${ }^{35}$. Sem prejuízo da origem divina, cogita-se no direito de resistência contra o soberano (Althusius) ${ }^{36}$. Com Hobbes, fortalece-se o poder do soberano e o primado da lei, que não precisa ser boa, pois o pacto civil implica transferência de direitos e a representação de todos os poderes, limitandose o direito de resistência ao direito à vida. O pacto envolve todos, menos o soberano, cujos atos são insindicáveis ${ }^{37}$.

Na transição para o século XVIII aconteceu uma grande ruptura de natureza política, social e também - o que nos interessa - jurisdicional. Mantém-se a noção de pacto como legitimador do poder, mas agora é um pacto civil, sem Deus. Locke acrescenta ao direito de resistência o direito à property ${ }^{38}$, bem como constrói o princípio da maioria ${ }^{39}$, com o que se reforça o primado da lei. Como a finalidade do Estado é proteger a propriedade, é preciso estabelecer uma lei, um juiz imparcial e um poder suficiente que respalde a sentença

\footnotetext{
${ }^{33}$ SCATTOLA, Merio - El Poder - Para uma História de La Filosofia Política Moderna, org. DUSO, Giuseppe, Siglo Veintiuno Editores, 2005, México.

${ }^{34}$ DUSSEL, Enrique - Politica de la Liberación - Historia Mundial y Crítica, p. 244, 2007, Editorial Trotta, Madri.

${ }^{35}$ SCATTOLA - op. cit.

${ }^{36}$ DUSO, Giuseppe - op. cit.

${ }^{37}$ A especificidade das relações do Estado e da Igreja, na Inglaterra de Hobbes, faz com que ele sustente um Estado cristão, mas que exerce seu poder até sobre a Igreja (no caso, a Anglicana), porque poder recebido de Deus (DUSSEL, p. 247, op. cit.).

${ }^{38}$ Importante acompanhar CAPRA na associação entre a física clássica (mecânica) e o pensamento de Locke, especialmente quanto à propriedade privada. Locke teria desenvolvido uma concepção atomista da sociedade, acreditando que as leis naturais - igualdade, liberdade e propriedade - governariam a sociedade humana. No pensamento medieval, a propriedade privada era aquela que, literalmente, privava o grupo social dos benefícios que proporcionava, em contraposição à propriedade comunal. A concepção atomista de Locke, em que preponderava o individualismo e as demais leis naturais, acabou por inverter a concepção de propriedade e o proprietário passou a ser protegido, pois não poderia ser privado da sua propriedade sem o devido processo legal (CAPRA, Fritjof - O Ponto de Mutação. São Paulo: Ed. Cultrix, 2006, ps. 64 e 197).

39 Advirta-se, logo, que o princípio da maioria de Locke e da modernidade de então nada tem de igualitário, pois Locke foi o filósofo do poder, mas do poder burguês. Seu princípio da igualdade, sobre o qual repousava o tal princípio da maioria, era exclusivo para os homens que fossem proprietários virtuosos, ficando excluídas as mulheres e os homens sem posses (DUSSEL, p. 268/281, op. cit.).
} 
Revista Eletrônica de Direito Processual - REDP.

Rio de Janeiro. Ano 13. Volume 20. Número 1. Janeiro a Abril de 2019

Periódico Quadrimestral da Pós-Graduação Stricto Sensu em Direito Processual da UERJ

Patrono: José Carlos Barbosa Moreira (in mem.). ISSN 1982-7636. pp. 288-314

www.redp.uerj.br

contra os culpados ${ }^{40}$. Para melhor garantir a propriedade e a segurança das relações sociais,

Hume propõe uma organização social que denomina de justiça, como derivação da necessidade da moral ${ }^{41}$. O pacto civil tem os pressupostos da igualdade substancial de todos e da vontade geral (Rousseau) ${ }^{42}$. As categorias poder, soberania, lei, direito, segurança são fortalecidas. O pacto civil e o direito de resistência transformam-se em poder constituinte. Mas logo se percebe o quanto é perigoso conceder ao povo um tal poder absoluto e, assim, ao lado do poder constituinte, concebe-se o poder constituído, mediante a teoria da representação, o princípio da igualdade formal e o primado da lei (Sieyés). Provoca-se, assim, o distanciamento entre a vida pública (gerida pelos representantes, eleitos por voto censitário) e a vida privada (a cargo dos representados); entre a vontade de todos e a lei ${ }^{43}$.

A experiência histórica da Inglaterra, quanto à separação de poderes, foi adotada na França revolucionária, a partir das obras de Bolingbroke (1738) e de Montesquieu (1748).

O direito natural passou a exercer a função de filtragem do direito romano e, ao mesmo tempo, como limite ao soberano. No que toca à jurisdição, a Inglaterra forneceu a inspiração para um modelo processual acusatório e garantista: acusação oficial, juiz natural e neutro, livre convencimento, contraditório, presunção de inocência e duplo grau (só implementado por Napoleão no século seguinte). O final do século XVIII ainda aporta à noção de juiz natural o conceito de equidistância, por influência da obra de Kant.

\footnotetext{
40 DUSSEL comenta que "su imparcialidad será intrinsicamente parcial, ya que deberá defender la propriedad de los que tienen contra los que no la tienen (op. cit, p. 320, nota 878). Acrescenta o autor: "La fetichización de los sistemas dominadores naturaliza las instituciones historicas (como la propriedad). El orden econômico (el capitalismo naciente), entonces, queda situado en el orden natural que el Estado deberá gestionar. Se encuentra ya la tesis central del liberalismo, que intentará siempre ocultar el sistema econômico (p. 278)...De manera que toda la estructura institucional política se organiza para defender una minoria contra la mayoría empírica: los no-proprietarios (p. 279).

${ }^{41}$ DUSSEL conclui que, para Hume, a justiça é que faz possível, faticamente, a sociedade burguesa industrial daquele tempo (op. cit., p. 326). Veja-se que o mito da segurança jurídica começa aqui, para proteger a propriedade, não só da terra, mas dos bens advindos da Revolução Industrial.

42 Não há dúvida que Rousseau é um crítico da obra da modernidade, mas sua idéia de igualdade de todos, de vontade geral, de pacto civil, integrou a trajetória daquela etapa histórica e contribuiu para o estudo da simbologia da lei que se pretende fazer aqui. Ele dirige sua crítica à sociedade e à lei: "Tal fue o debió ser el origen da la sociedad y de las leyes, que pusieron nuevas dificuldades a los débiles y nuevas fuerzas a los ricos, destruyeron sin retorno la libertad natural, fijaron para siempre la ley de la propriedad y la desigualdad, de una pura usurpación hicieron un derecho irrevocable...sometieron a todo el género humano al trabajo, a servidumbre y a la miséria (apud, DUSSEL, op. cit., p. 348/349). O pensamento de Rousseau foi tão crítico como utópico, utopia que ele próprio reconheceu, mas sonhou que se concretizaria no futuro.

${ }^{43}$ DUSO, Giuseppe - op. cit.
} 
Revista Eletrônica de Direito Processual - REDP.

Rio de Janeiro. Ano 13. Volume 20. Número 1. Janeiro a Abril de 2019

Periódico Quadrimestral da Pós-Graduação Stricto Sensu em Direito Processual da UERJ

Patrono: José Carlos Barbosa Moreira (in mem.). ISSN 1982-7636. pp. 288-314

www.redp.uerj.br

Nesse novo cenário que eclodiu na França e que repercutiu em toda a Europa

Continental, a justiça teve de se modificar e a jurisdição rompeu com o processo inquisitivo e suas penas cruéis. Teve um papel relevante a denominada Escola Clássica de Direito Penal, pregando a humanização das penas. No seu bojo, o crime foi visto como um atentado ao contrato social, que carecia de ser prevenido por meio da pena, que assumia, assim, uma função utilitarista de prevenção geral por meio da dissuasão.

A lógica do sistema criminal passou a ser pretensamente racional, apoiada na onipotência da lei e no monismo jurídico. Consequentemente, a simbologia da justiça teve que se afastar dos motivos religiosos e, para isso, adotou a venda, com o sentido simbólico antropocêntrico, de voltar-se para o interior do ser humano julgador, compreendido como inteiramente capaz de julgar racionalmente, e cortando-se qualquer possível vínculo com o mundo exterior ${ }^{44}$. $\mathrm{O}$ processo moderno europeu continental, enfim, tendeu à modernização, com oralidade e simplicidade ${ }^{45}$, e à humanização ${ }^{46}$.

Surge a terceira teoria criminológica, retribucionista, influenciada por Kant e por Hegel. Para o primeiro a pena é um imperativo categórico, cuja necessidade não tem como ser explicada racionalmente. Para o segundo a pena é a negação ao crime, que é a negação do direito.

O século XVIII, com todas as transformações que gerou, entronizou a democracia parlamentar associada ao liberalismo econômico.

As conquistas garantistas da Revolução Francesa, porém, não foram inteiramente implantadas, nem mesmo na França, no século seguinte - século XIX. Na verdade, as promessas de liberdade, igualdade e fraternidade não foram inteiramente cumpridas. O terceiro estado - cuja insatisfação foi o motor da Revolução, em oposição à nobreza e ao clero - continuou sendo preterido na repartição da riqueza, que agora se deslocava da nobreza para a burguesia. Tal descontentamento fomentou revoltas na França e teorias políticas que, posteriormente, fundamentaram o socialismo, o anarquismo e o marxismo.

Nesse cenário de desordem e de caos social, Napoleão assumiu o poder, declarando-se um filho da revolução e, portanto, colocando-se em posição oposta às

\footnotetext{
${ }^{44}$ GARAPON, Antoine - op. cit.

${ }^{45}$ Não só o direito inglês era mais simples e oral, mas, também, antigas leis germânicas.

${ }^{46}$ Reivindicação da Escola Clássica de Direito Penal.
} 
Revista Eletrônica de Direito Processual - REDP.

Rio de Janeiro. Ano 13. Volume 20. Número 1. Janeiro a Abril de 2019

Periódico Quadrimestral da Pós-Graduação Stricto Sensu em Direito Processual da UERJ

Patrono: José Carlos Barbosa Moreira (in mem.). ISSN 1982-7636. pp. 288-314

www.redp.uerj.br

monarquias absolutas do resto da Europa. Internamente, Napoleão logrou imprimir ordem e estabilidade ao país.

A tendência para o monismo jurídico e para o reconhecimento da onipotência da lei levaram ao movimento de codificação, instaurado por Napoleão, que também repercutiu em toda a Europa Continental. O sistema acusatório adversarial francês vigorou por muito pouco tempo e foi prontamente substituído por um modelo processual misto, orientado por um princípio de investigação oficial e pelo livre convencimento, o que redundou na proeminência da função processual do juiz, especialmente do juiz criminal, ao qual se reconheceu poderes estatais para a descoberta da verdade.

No entanto, o grande marco deste século foi o surgimento do positivismo, doutrina do francês Auguste Comte, surgida na França, em $1830^{47}$, da qual decorreu o positivismo jurídico, que marcou profundamente o Direito e o modo de funcionamento dos sujeitos processuais, não só no século XIX, mas no XX, também, e cuja influência chega até os presentes dias.

Apesar da doutrina de Comte apoiar-se na historicidade, o positivismo jurídico dela foi se afastando. O ápice desse divórcio entre historicidade e legislação deu-se, por ironia, com a obra de Hans Kelsen ${ }^{48}$. Por ironia porque, ao construir sua teoria, ao

\footnotetext{
${ }^{47}$ Auguste Comte (1798/1857) foi autor do Curso de Filosofia Positiva, no qual propunha que o conhecimento passa por três estados: o teológico, o metafísico e o positivo, este último, o mais evoluído. No teológico, a mente humana procura as causas e princípios das coisas, até o mais profundo grau de acessibilidade, remontando, na origem, a um poder divino, até encontrar Deus, fase mais evoluída desse estado. Corresponde à infância da humanidade. No metafísico, procura explicar a natureza dos seres, suas essências e suas causas, mas não recorre a agentes sobrenaturais, mas a entidades abstratas (ontologia). É um estado essencialmente crítico, que deixa de procurar o longínquo e se aproxima das coisas, substituindo a entidade Deus pela natureza. Significa a puberdade do espírito humano. O estado positivo é o definitivo. A mente humana se atém às coisas e suas leis, descurando de causas, princípios ou essências das coisas, reconhecendo suas inutilidades por serem inacessíveis. Procura examinar os fatos e suas leis, tão somente. Mas esse exame é relativo à organização social. Não se trata de ideias individuais, mas sociais e coletivas e dependem, portanto, da história. Comte defende que o sistema que explicar o passado será o dono do futuro. A continuidade histórica e o equilíbrio social podem realizar o lema ordem e progresso. De acordo com Julian Marías, "o saber positivo se atém humildemente às coisas; fica diante delas, sem intervir, sem pular por cima para lançar-se em falaciosos jogos de ideias; não pede mais causas, tão somente leis. E graças a essa austeridade, consegue obter essas leis e as possui com precisão e certeza...Vemos, pois, que por trás de seu naturalismo científico há, em Comte, de maneira essencial, um pensamento histórico..." (MARÍAS, Julian. História da Filosofia. São Paulo: Martins Fontes, 2004).

${ }^{48}$ Teoria Pura do Direito, $6^{a}$ ed., 1984, Armenio Amado Editora, Coimbra.
} 
Revista Eletrônica de Direito Processual - REDP.

Rio de Janeiro. Ano 13. Volume 20. Número 1. Janeiro a Abril de 2019

Periódico Quadrimestral da Pós-Graduação Stricto Sensu em Direito Processual da UERJ

Patrono: José Carlos Barbosa Moreira (in mem.). ISSN 1982-7636. pp. 288-314

www.redp.uerj.br

pretender afastar o Direito de ideologias ${ }^{49}$ e da moral ${ }^{50}$, acabou por pavimentar os

argumentos a favor de uma interpretação puramente literal das normas jurídicas, em que as ideologias se instalaram no Direito, sem qualquer preocupação com os ideais de justiça e com a realidade social. Anestesiou-se o Direito e o seu aplicador, aferrado que ficou a um princípio de legalidade por si só justificante de qualquer decisão judicial.

$\mathrm{O}$ tal ato de $\operatorname{vontade}^{51}$ na interpretação do Direito ficou alheio à concepção positivista do Direito, limitando-se, muitíssimas vezes, a jurisprudência, dita tradicional, a aplicar a lei de forma mecânica e sem levar em consideração a justiça da decisão. Não que o ato de vontade, tão só e simplesmente, se apresente como apanágio da decisão correta, pois muitas vezes não é nem correta, nem legítima. Mas serve a referência para sublinhar o mecanicismo que imperou e ainda, em certa medida, impera na jurisprudência originada no positivismo jurídico $^{52}$ e que apazigua a consciência dos julgadores que remetem, à lei, a responsabilidade por suas decisões.

Também não valeram as advertências ainda mais remotas de Hegel $^{53}$ que, valendo-se de Montesquieu, propunha não perder-se de vista as circunstâncias históricas da legislação.

\footnotetext{
49 “Se por ideologia se entende, porém, não tudo o que não é a realidade natural ou sua descrição, mas uma representação não-objectiva, influenciada por juízos de valor subjectivos, que encobre, obscurece, ou desfoca o objecto de conhecimento, e se se designa por realidade, não apenas a realidade natural como objecto da ciência da natureza, mas todo o objecto do conhecimento e, portanto, também o objecto da ciência jurídica, o Direito positivo como realidade jurídica, então também uma representação do Direito positivo se tem de manter isenta de ideologia....Neste sentido a teoria pura do direito tem uma pronunciada tendência antiideológica...Neste sentido é uma teoria do Direito radicalmente realista, isto é, uma teoria do positivismo jurídico" ( op. cit., p. 160/161, tradução de João Batista Machado, 6ª edição, 1984, Armênio Amado Editora, Coimbra).

50 "o direito pode ser moral - no sentido acabado de referir, isto é, justo - mas não tem necessariamente de o ser...se bem que se admita a exigência de que o Direito deve ser moral, isto é, deve ser justo." - ibidem, p. 100.

51 "Na aplicação do Direito por um órgão jurídico, a interpretação cognoscitiva...do Direito a aplicar combina-se com um acto de vontade em que o órgão aplicador do Direito efectua uma escolha entre as possibilidades reveladas através daquela mesma interpretação cognoscitiva" - ibidem, p. 470.

${ }_{52}$ Muitas são as configurações atuais do positivismo: o positivismo doutrinário político sustenta que as considerações teóricas gerais, incluindo as éticas e filosóficas, só são relevantes para a identificação do direito na medida se as próprias regras jurídicas o permitam (Hart); o positivismo sociológico sustenta que os juízos morais não são adequados para distinguir o direito de outras formas de organização política e social; o positivismo taxonômico nega que o direito contenha qualquer princípio moral; o positivismo político (Holmes e Hand) prega que os juízes não tentem completar as deliberações dos legisladores, pois os cidadãos, não os juízes, é que devem decidir sob que leis querem ser governados; o positivismo exclusivo (Joseph Raz) afirma que o direito não pode nunca depender de critérios morais; o positivismo inclusivo (Coleman) defende que os juízos morais só podem ser usados se a comunidade os estipular (Cfr. DWORKIN, Ronald - La Justicia con Toga, 2007, Ed. Marcial Pons, Madri).

${ }^{53}$ Op. cit., Princípios da Filosofia do Direito, p. 20/21. O autor sustenta: "Grave erro seria extrair, da afirmada diferença entre o direito natural ou filosófico e o direito positivo, a conclusão de que se opõem ou
} 
Revista Eletrônica de Direito Processual - REDP.

Rio de Janeiro. Ano 13. Volume 20. Número 1. Janeiro a Abril de 2019

Periódico Quadrimestral da Pós-Graduação Stricto Sensu em Direito Processual da UERJ

Patrono: José Carlos Barbosa Moreira (in mem.). ISSN 1982-7636. pp. 288-314

www.redp.uerj.br

No plano do direito processual, uma onda de cientificismo e racionalismo deu

origem à fase científica do direito processual civil. A proeminência da posição do magistrado foi corroborada pela filosofia de Hegel para o qual não há poder fora do estado e da constituição, e pela sua ${ }^{54}$ concepção da relação jurídica processual ${ }^{55}$ com o juiz e mais dois sujeitos processuais (autor e réu), desenvolvida posteriormente por Bulow ${ }^{56}$. Especialmente por esforço dos juristas alemães, foi sendo suplantado o procedimentalismo francês, mais simples e oralizado, substituído por um direito processual teoricamente mais robusto e que permitiu a sua autonomia científica. Não só surgiu a teoria do processo como relação jurídica, mas, também, as teorias da ação: de Savigny (Escola Histórica); de Windscheid (1856)/Muther(1857); de Degenkolb (1877)/Plósz (1880); e de Wach (1885).

As noções vindas do direito processual civil acabaram por embasar a doutrina dedicada ao direito processual penal.

O desenvolvimento do positivismo, desse modo, marcou profundamente este século e suas instituições. A demanda por ordem, certeza e disciplina influenciou todas as instituições desse tempo. Convém acompanhar Boaventura de Souza Santos ${ }^{57}$ para bem apreender as mudanças provocadas pelo positivismo e sua associação ao modelo capitalista.

Segundo o autor, o desenvolvimento do capitalismo deu-se em três fases distintas. Numa

contradizem...foi Montesquieu quem definiu a verdadeira visão histórica, o verdadeiro ponto de vista filosófico, que consiste em não considerar isolada e abstratamente a legislação geral e suas determinações, mas vê-las como elemento condicionado de uma totalidade e correlacionadas com as outras determinações que constituem o caráter de um povo e de uma época; nesse conjunto adquirem elas o seu verdadeiro significado e nisso encontram portanto a sua justificação".

${ }^{54}$ Para maior fidedignidade, convém citar o trecho pertinente: "221. O membro da sociedade civil tem o direito de assistir ao julgamento e o dever de se apresentar perante o tribunal e de só perante o tribunal reivindicar o reconhecimento de um direito contestado. 222. Perante os tribunais, o direito tem o caráter de um dever-ser demonstrado. O processo dá às partes as condições para fazerem valer os seus meios de prova e motivos jurídicos e ao juiz as de conhecer o assunto. As fases do processo são elas próprias direitos. As suas ligações também devem, por isso, ser definidas juridicamente, o que constitui uma parte essencial da ciência teórica do direito. 223. Com a sua divisão em atos sempre mais particulares e nos direitos correspondentes, segundo uma complicação que não tem limite em si mesma, o processo, que começara por ser um meio, passa a distinguir-se da sua finalidade como algo extrínseco. Têm, as partes a faculdade de percorrer todo o formalismo do processo, o que constitui o seu direito, e isso pode tornar-se um mal e até um veículo de injustiça. Por isso, para proteger as partes e o próprio direito, que é aquilo de que substancialmente se trata, contra o processo e os seus abusos deverá o tribunal submeter-se a uma jurisdição simples (tribunal arbitral, tribunal de paz) e prestar-se a tentativas de acordo antes de entrar no processo" (Op. cit., ps. 196/197).

${ }^{55}$ Op. cit. Tradução de Orlando Vitorino. 1 ed. São Paulo: Martins Fontes, 1997. 1997. A primeira menção a uma relação processual foi feita por Búlgaro no século XII.

${ }^{56}$ BÜLOW, Oskar von. Teoria das Exceções e dos Pressupostos Processuais. Tradução de Ricardo Rodrigues Gama, a partir da edição espanhola. 2 ed. Campinas: LZN Editora, 2005.

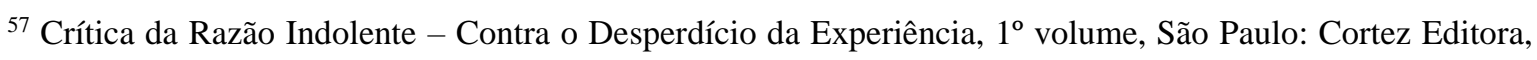
2011, pgs 140/164. 
Revista Eletrônica de Direito Processual - REDP.

Rio de Janeiro. Ano 13. Volume 20. Número 1. Janeiro a Abril de 2019

Periódico Quadrimestral da Pós-Graduação Stricto Sensu em Direito Processual da UERJ

Patrono: José Carlos Barbosa Moreira (in mem.). ISSN 1982-7636. pp. 288-314

www.redp.uerj.br

primeira fase, no século XIX, chamada de capitalismo liberal, foi preciso minimizar os ideais

éticos e as promessas públicas de liberdade, igualdade e fraternidade do século anterior. A ordem positivista serviu de instrumento para regular o capitalismo liberal e para tornar a sociedade mais previsível e certa. Por outro aspecto, o positivismo serviu para imunizar qualquer racionalidade não capitalista. Dessa forma, o direito foi diretamente usado para deter e controlar alguns dos problemas decorrentes da industrialização: pobreza, prostituição, criminalidade, alcoolismo, epidemias, analfabetismo, greves, desemprego e a subversão socialista.

Numa segunda etapa, que o autor identifica entre 1870 até 1960 e denomina de capitalismo organizado, o positivismo serviu para impor uma gestão econômica diante da complexidade da economia capitalista, mediando os interesses empresariais, de um lado, e uma política de providência (estado-providência), de outro ${ }^{58}$.

No plano criminológico, uma quarta teoria surge, também utilitarista, incentivada pela Escola Positiva de Direito Penal e influenciada por Lombroso (antropologia), Ferri (sociologia) e Garofalo (psicologia), que viam o criminoso como um ser desviado e doente, para o qual propunham a prevenção especial negativa pela neutralização (pena terapia) e a prevenção especial positiva pela correção (pena medicina)

O século XX é um verdadeiro caleidoscópio de complexidades. Os movimentos políticos bem o demonstram: liberalismo, nazismo, fascismo e comunismo responderam por boa parte dessa complexidade e levaram a humanidade a duas guerras mundiais.

No aspecto criminológico, várias teorias dividiram as atenções dos juristas. Uma, também utilitarista, influenciada por Durkheim, no século XIX, mas desenvolvida e difundida no princípio do século XX, era baseada na concepção de que o criminoso não era um doente patológico, apenas tinha dificuldade de aceitar o papel social da divisão do trabalho. Propunha, assim, a sua integração, como forma de prevenção social positiva. A outra teoria, a criminologia crítica, que surge anos mais tarde, foi desenvolvida

\footnotetext{
${ }^{58}$ Para o autor, esse pacto entre empresa e trabalho redundou na redução dos ideais de emancipação a proporções realistas e exequíveis, numa sociedade capitalista dominada pelo intuito do lucro (BOAVENTURA, op. cit.). Para oele, numa terceira etapa, que denomina de capitalismo desorganizado, já no século seguinte, por volta da década de $70 \mathrm{em}$ diante, se instala a crise na política do Estado-providência: as promessas de distribuição mais justa dos benefícios e de um sistema político estável começaram a se deteriorar e se instala o neoliberalismo, que demove o estado de seu papel de regular a sociedade, em prol de uma economia de mercado pretensamente livre de amarras.
} 
Revista Eletrônica de Direito Processual - REDP.

Rio de Janeiro. Ano 13. Volume 20. Número 1. Janeiro a Abril de 2019

Periódico Quadrimestral da Pós-Graduação Stricto Sensu em Direito Processual da UERJ

Patrono: José Carlos Barbosa Moreira (in mem.). ISSN 1982-7636. pp. 288-314

www.redp.uerj.br

especialmente por Alessandro Baratta, com base em conceitos marxistas, como a divisão da

sociedade em classes sociais e a luta de classes. Entendia que o direito penal era uma cobertura ideológica para exercer controle contra os "perigosos", que era, usualmente, os pobres. A terceira, foi o abolicionismo penal, desenvolvida por Louk Hulsman, que diante da falência da pena, propunha a sua abolição, mas não a abolição da punição, que deveria ser ajustada entre o criminoso e a vítima, substituindo-se a lei penal pela lei civil, a pena pela composição e pelo ressarcimento ${ }^{59}$.

No âmbito do direito penal, a teoria causal-naturalista, presa às concepções da física mecânica, acaba sendo substituído pela teoria finalista da ação, desenvolvida por Welzel, que usa, como conceito central, a ideia da intenção, tomada da corrente filosófica denominada fenomenologia, desenvolvida por Husserl, no princípio do século XX.

Direitos e garantias foram sacodidas ao sabor dessas concepções políticas, negadas absolutamente em determinados países e em determinados tempos históricos; alçados a um patamar mais elevado em outro. A crítica à democracia liberal levou à concepção do socialismo, do comunismo, do nazismo e do fascismo ${ }^{60}$. Estas duas últimas

\footnotetext{
${ }^{59}$ BATISTA, Nilo e KOSOVSKI, Ester (org). Tributo a Louk Hulsman. Rio de Janeiro: Ed. Revan, 2012.

60 Fascismo é uma forma de radicalismo político autoritário nacionalista que ganhou destaque no início do século XX na Europa e teve origem na Itália. Os fascistas procuravam unificar sua nação através de um Estado totalitário que promove a vigilância, um estado forte, a mobilização em massa da comunidade nacional, confiando em um partido de vanguarda para iniciar uma revolução e organizar a nação em princípios fascistas, hostis a todas as vertentes do marxismo, desde o comunismo totalitário ao socialismo democrático. Os movimentos fascistas compartilham certas características comuns, incluindo a veneração ao Estado, a devoção a um líder forte e uma ênfase em ultranacionalismo, etnocentrismo e militarismo. O fascismo vê a violência política, a guerra, e o imperialismo como meios para alcançar o rejuvenescimento nacional e afirma que as nações e raças consideradas superiores devem obter espaço deslocando ou eliminando aquelas consideradas fracas ou inferiores, como no caso da prática fascista modelada pelo nazismo. $\mathrm{O}$ fascismo tomou emprestado teorias e terminologias do socialismo e aplicou-as sob o ponto de vista que o conflito entre as nações e raças fosse mais significativo, mas também tendo foco em acabar com as divisões de classes dentro da nação. Defendeu uma economia mista, com o objetivo principal de conseguir autarquia para garantir a autosuficiência, e a independência nacional através de protecionismo e políticas econômicas que intercalam intervencionismo e privatização. $\mathrm{O}$ fascismo sustenta o que é, às vezes, chamado de Terceira posição entre o capitalismo e o socialismo marxista. Influenciados pelo sindicalismo nacional, os primeiros movimentos fascistas surgiram na Itália, cerca da Primeira Guerra Mundial, combinando elementos da política de esquerda[ com mais tipicamente a política de direita, em oposição ao socialismo, ao comunismo, à democracia liberal e, em alguns casos, ao conservadorismo tradicional. Embora o fascismo seja geralmente colocado na extrema-direita no tradicional espectro esquerda-direita, alguns comentaristas argumentam que a descrição é inadequada. Benito Mussolini, em A Doutrina do Fascismo, afirmou que o fascismo era uma ideologia de direita.
}

Nacional-Socialismo (em alemão: Nationalsozialismus), mais comumente conhecido como nazismo, é a ideologia associada ao Partido Nazista, ao Estado nazista, bem como a outros grupos de extremadireita. Normalmente caracterizado como uma forma de fascismo que incorpora o racismo científico e o antissemitismo, o nazismo se desenvolveu a partir das influências de ideias pangermânicas, do movimento nacionalista alemão Völkisch e de grupos paramilitares anticomunistas chamados Freikorps, que surgiram durante a República de Weimar após a derrota alemã na Primeira Guerra Mundial. O termo "nacional- 
Revista Eletrônica de Direito Processual - REDP.

Rio de Janeiro. Ano 13. Volume 20. Número 1. Janeiro a Abril de 2019

Periódico Quadrimestral da Pós-Graduação Stricto Sensu em Direito Processual da UERJ

Patrono: José Carlos Barbosa Moreira (in mem.). ISSN 1982-7636. pp. 288-314

www.redp.uerj.br

tendências políticas provocaram a II Guerra Mundial e o holocausto de judeus, ciganos, homossexuais, socialistas e comunistas, sob a batuta de Hitler e de Mussolini.

Foi por conta dessas mazelas, quase sempre concebidas com a aparência de

legalidade, que a humanidade e as nações acordaram para a necessidade de uma ordem constitucional capaz de conter o arbítrio legal, e, depois, uma ordem supranacional, que pudesse conter o arbítrio dos estados nacionais. Foram, assim, surgindo o constitucionalismo $^{61}$, as declarações universais e regionais de direitos e o reconhecimento da categoria dos direitos humanos.

No plano processual, prosseguiu a fase científica do processo: segue nova teoria sobre o processo com Goldschmidt (1925); teorias da ação, com Chiovenda (1903), Goldschmidt (1925), Liebman (1949); teorias sobre a coisa julgada, com Redenti, Carnelutti e Liebman. Surge, também, a teoria do garantismo, com as dez máximas assaz conhecidas de Luigi Ferrajoli ${ }^{62}$ : nulla poena sine crimine, nullum crimine sine lege, nulla lex poenalis sine necessitate, nulla necessita sine inuiuria, nulla iniuria sine actione, nulla actio sine

socialismo" surgiu a partir da tentativa de redefinição nacionalista do conceito de "socialismo", para criar uma alternativa tanto ao socialismo internacionalista marxista quanto ao capitalismo de livre mercado. A ideologia rejeitava o conceito de luta de classes, assim como defendia a propriedade privada e as empresas de alemães. $\mathrm{O}$ nazismo apoiava teorias como a hierarquia racial e o darwinismo social, sendo que os povos germânicos (chamados de raça nórdica) eram descritos como os mais puros da raça ariana e eram, portanto, vistos como a "raça superior". O movimento tinha como objetivo superar as divisões sociais para criar uma sociedade homogênea, ao mesmo tempo em que buscava unidade nacional e tradicionalismo. Os nazistas tentaram conseguir isto através de uma "comunidade do povo" (Volksgemeinschaft) que iria unir todos os alemães e excluir aqueles considerados como "povos estrangeiros" (Fremdvölkische). O nazismo também reivindicava com determinação o que entendia ser territórios historicamente alemães sob a doutrina pangermânica (ou Heim ins Reich), bem como áreas adicionais para colonização alemã sob a doutrina de Lebensraum. O Partido Nacional Socialista dos Trabalhadores Alemães (Nationalsozialistische Deutsche Arbeiterpartei, NSDAP) foi fundado em 5 de janeiro de 1919. No início dos anos 1920, Adolf Hitler assume o controle da organização e rebatiza-a para Partido Nazista. O Programa Nacional Socialista, aprovado em 1920, apelava por uma Grande Alemanha unida e que negaria cidadania aos judeus ou aos seus descendentes, além de apoiar a reforma agrária e a nacionalização de algumas indústrias. Em Mein Kampf, escrito em 1924, Hitler delineou o antissemitismo e o anticomunismo no cerne de sua filosofia política, bem como o seu desdém pela democracia parlamentar e sua crença no direito da Alemanha expandir seu território. Em 1933, com o apoio das elites alemãs, Hitler tornou-se chanceler e os nazistas gradualmente estabeleceram um regime unipartidário e totalitário, onde judeus, opositores políticos e outros elementos vistos como "indesejáveis" eram marginalizados, escravizados, presos e assassinados. Hitler expurgou as facções sociais e econômicas mais radicais do partido em meados de 1934, durante a chamada Noite das Facas Longas. Após a morte do presidente Paul von Hindenburg, o poder político foi concentrado nas mãos do Führer (ou "líder"). No entanto, após o Holocausto e a derrota alemã na Segunda Guerra Mundial, apenas alguns grupos radicais racistas, geralmente referidos como neonazistas, ainda descrevem-se como "nacional-socialistas". (Wikipedia, acesso em 17/09/2018).

${ }^{61}$ Diante da necessidade de as constituições limitarem a lei, por conta da constatação de que regimes de exceção podem ser constituídos com fundamento na legislação.

${ }^{62}$ Direito e Razão: Teoria do Garantismo Penal. Tradução de Ana Paula Zomer, Fauzi Hassan Choukr, Juarez Tavares e Luiz Flávio Gomes. São Paulo: Revista dos Tribunais, 2002. 
Revista Eletrônica de Direito Processual - REDP.

Rio de Janeiro. Ano 13. Volume 20. Número 1. Janeiro a Abril de 2019

Periódico Quadrimestral da Pós-Graduação Stricto Sensu em Direito Processual da UERJ

Patrono: José Carlos Barbosa Moreira (in mem.). ISSN 1982-7636. pp. 288-314

www.redp.uerj.br

culpa, nulla culpa sine iudicio, nullum iudicium sine accusatione, nulla accusatio sine

probatione e nulla probatio sine difensione.

Ao mesmo tempo - e paradoxalmente - o final do século XX assistiu o surgimento de movimentos de recrudescimento: lei e ordem $^{63}$, direito penal do inimigo ${ }^{64}$, teoria das janelas quebradas ${ }^{65}$; bem como uma forte tendência à universalização de métodos tecnológicos de investigação e combate à criminalidade organizada e ao terrorismo, com a previsão de cooperação internacional ${ }^{66}$; além da introdução de uma justiça negocial no âmbito criminal, também chamada de direito penal premial, ou equivalentes funcionais à sanção penal (podendo ter a natureza de uma transação sobre a pena ou uma transação sobre o procedimento).

Todos esses movimentos e tendências decorrem do estado de insegurança em que o mundo foi lançado ao final do século e que persiste até nossos dias, o que permite dizer que o século XX termina com uma grave crise e que esta será o signo sob a qual se inicia o século seguinte.

\footnotetext{
${ }^{63}$ Movimento surgido nos anos 70 contra uma suposta leniência ao crime e pugnando pelo recrudescimento das penas, desenvolvido por James Wilson e Ernest Van Der Haag (BATISTA, Vera Malaguti. Introdução Crítica à Criminologia Brasileira. Rio de Janeiro: Ed. Revan, pgs. 102/103, 2011).

${ }^{64}$ JAKOBS, Günther, e MELIÁ, Manuel Cancio. Direito Penal do Inimigo - Noções e Críticas. 3 ed. Porto Alegre: Livraria do Advogado, 2008. O direito penal do inimigo se caracterizaria pelo adiantamento da punibilidade (para o fato futuro), penas desproporcionalmente altas e supressão ou relativização das garantias processuais. Ainda que o autor tente justificar que o direito penal do inimigo é menos perigoso, pois delimita esse tipo de reação estatal, em vez de contaminar todo o direito penal, a tese não pode ser acolhida, porque revela uma contradição em termos: o direito penal do inimigo não pode ser considerado direito. Por isso, Manuel Cancio Meliá a ele se refere como o não-direito penal ( $o p$. cit., p. 66), capaz de vulnerar o tradicional direito penal do fato e de substituí-lo pelo direito penal do autor (op. cit., p. 80). Os inimigos, para, por exemplo, Jakobs, são os que se conduzem de modo desviado, não oferecendo garantia de seu comportamento pessoal e, por isso, não podem esperar ser tratados como pessoas e, de fato, o estado não deve tratá-los como pessoas, em nome da segurança da coletividade. A categoria dos inimigos, deserdados da cidadania, não é nova, nem na história da filosofia. O próprio Jakobs retirará da filosofia de Hobbes e de Kant os fundamentos de sua tese. Mas, talvez, o seu mais eficiente patrocinador, do ponto de vista prático, tenha sido o filósofo que é considerado o arauto dos direitos humanos, por incrível que isso possa parecer: John Locke (1632 a 1704). Assim, em seu Segundo Tratado sobre o Governo Civil e no Ensaio sobre o Governo Civil, escritos em 1690 e 1697, respectivamente, Locke discorre sobre o poder do estado de estabelecer a pena capital; sobre considerar o culpado como um perigo para a sociedade; sobre a perda da condição de parte de uma sociedade civil; sobre a punição de mendigos e de crianças e, até mesmo, a perda das orelhas para quem falsificar um passe de viagem (LOCKE, John. Segundo Tratado sobre o Governo Civil, disponível em http://www.xr.pro.br/IF/LOCKE-Segundo tratado_Sobre_O_Governo.pdf, acesso em 16 junho 2016).

${ }^{65}$ Desenvolvida no governo Reagan, nos EUA, a partir de 1981, pugna pela criminalização dos pequenos delitos, como condutas desordeiras ou antissociais (BATISTA, op. cit.).

${ }^{66}$ Declaração Universal dos Homens, preâmbulo (1948). Convenção das Nações Unidas sobre o Crime Organizado Transnacional (Nova York, 2000). Protocolo de Assistência Jurídica em Matéria Penal do Mercosul (2000).
} 
Revista Eletrônica de Direito Processual - REDP.

Rio de Janeiro. Ano 13. Volume 20. Número 1. Janeiro a Abril de 2019

Periódico Quadrimestral da Pós-Graduação Stricto Sensu em Direito Processual da UERJ

Patrono: José Carlos Barbosa Moreira (in mem.). ISSN 1982-7636. pp. 288-314

www.redp.uerj.br

O início do século XXI assiste, progressivamente, o incremento da sensação de insegurança em quase todos os cantos da Terra, em razão do terrorismo, do extremismo e da intolerância religiosos, da intolerância causada pela imigração, em razão da acentuação da pobreza e da concentração da renda, bem como em razão da polarização política. $O$ surgimento do Estado Islâmico contribui sobremaneira para o estado de insegurança e de intolerância, provocando guerras em vários países. Essa sensação de insegurança e de intolerância leva, sem dúvida, a demandas por mais segurança e a consequente fragilização das garantias.

Esse é o signo sob o qual estamos vivendo: a despositivação do sistema de garantias e a exigência por governos fortes, protecionistas, nacionalistas, todos com viés autoritário, conformando uma ideologia securitária.

No plano do Judiciário, o que se afigura é também um judiciário menos democrático, menos contraditório - ou somente formalmente contraditório -, que possa dar voz aos anseios populares de segurança e que combata fortemente tudo que represente risco a ela. Em outras palavras, um juiz que valore as garantias sob o prisma do interesse coletivo, locução que pode muito bem acomodar o interesse público, ou o interesse da classe detentora do poder.

A prudência recomenda que não se delongue no exame deste século, pois há ainda muitos anos a correr, mas corremos o risco dessa ideologia persistir e se fortalecer, pondo em sério risco as conquistas democráticas e o avanço dos direitos humanos que foi o marco significativo dos anos do pós-guerra.

Talvez segurança e o combate à corrupção sejam os motes, ou o núcleo de uma atual jurisprudência dos valores, principalmente no Brasil. Seguindo Karl Larenz ${ }^{67}$, a denominada jurisprudência de valoração, surgida na Alemanha no século XX, especialmente no direito privado, em resposta ao positivismo jurídico, foi um desdobramento natural da jurisprudência dos interesses, na medida em que toda lei é produto de interesses contrapostos e é sempre preciso estabelecer ponderações entre os vários interesses contraditórios contemplados pelas leis. Além disto, o legislador muitas vezes se utiliza de conceitos indeterminados, cláusulas gerais, exigindo do juiz uma valoração adicional. Desta forma, além da subsunção da conduta à norma, que pressupõe uma interpretação prévia, com a

\footnotetext{
${ }^{67}$ Metodologia da Ciência do Direito. Tradução de José Lamego. Lisboa: Fundação Calouste Gulbenkian, $3^{\mathrm{a}}$ edição, 1997.
} 
Revista Eletrônica de Direito Processual - REDP.

Rio de Janeiro. Ano 13. Volume 20. Número 1. Janeiro a Abril de 2019

Periódico Quadrimestral da Pós-Graduação Stricto Sensu em Direito Processual da UERJ

Patrono: José Carlos Barbosa Moreira (in mem.). ISSN 1982-7636. pp. 288-314

www.redp.uerj.br

apreciação dos fatos, a constatação dos textos, e de circunstâncias variadas relevantes à

interpretação, é necessário também observar a razoabilidade. Larenz advoga a tese da

cientificidade desse método, desde que observados alguns procedimentos metodológicos ${ }^{68}$.

Esta diversidade de critérios de interpretação não hierarquizados é

considerada por alguns autores como arbitrária. A grande questão a enfrentar é se tal método,

que procura uma valoração subjacente à lei é científico, especialmente a partir de Weber,

\begin{abstract}
${ }^{68}$ Segue o raciocínio de Larenz para melhor compreensão: Não só o método permite uma correta interpretação da lei, como autoriza o desenvolvimento do Direito. Para ele, o juiz deveria considerar a ética vigente em sua comunidade jurídica como critério de julgamento, parâmetro que seria predado ao Direito e pelo qual ele terá de se orientar. Mas se, ainda assim, uma norma for manifestamente injusta, ou mesmo que várias normas de um mesmo ordenamento jurídico estejam em contradição, ganharia relevância os princípios éticos-jurídicos, que diferentes das leis, não são postos em vigência pelo legislador, pois surgem por si próprios na sociedade. Desta forma, uma norma que colide com um destes princípios não possui validade. Passando a analisar o conteúdo da norma, o autor aduz que a norma que está na lei necessita de clarificação e precisão que será realizada pelo juiz. Assim, a norma que está na lei, seria apenas o ponto de partida da atividade judicial. Para decidir um caso seria necessária a construção de uma norma mais estrita, chamada norma decisória. A base decisória da sentença não estaria simplesmente no texto da norma, mas deveria ser elaborada pelo juiz, não bastando uma simples subsunção. Contudo, alerta, não é possível achar a solução justa de uma situação concreta desconsiderando a lei e trabalhando apenas com as diversas técnicas de interpretação, priorizando o juízo de valor pessoal do juiz. Se o elemento de precisão da norma estiver suficientemente definido, bastará a subsunção lógica. Se não estiver, deverá ser realizada a comparação de casos, ordenação a um tipo ou o esclarecimento de um princípio subjacente. Ainda analisando a busca da decisão justa, o autor reconhece que os juristas em geral argumentam topicamente em diversos momentos, mas uma mera utilização da tópica, de pontos de vista relevantes no plano jurídico, de "um catálogo de tópicos", não se alcança o resultado desejado, que seria a decisão justa. Nem a mera subsunção, nem os métodos tradicionais de interpretação são suficientes para alcançar a decisão justa e simultaneamente conforme o direito vigente. O jurista, ao se orientar no direito positivo, pressupõe a existência de um nexo entre este e a sua aptidão de justificação racional. Este nexo consiste em que o texto só pode ser corretamente interpretado quando ele se faz subjazer a intenção de racionalidade e imparcialidade. Assim, a fidelidade à lei e a aspiração à justiça na concretização judicial do direito não se excluem entre si, mas antes se condicionam. Descobrir qual a decisão justa é a função da jurisprudência. A jurisprudência pode ser caracterizada como ciência do Direito que dele se ocupa sob o aspecto normativo, incluindo as decisões contidas em sentenças judiciais. É limitada porque o jurista estará sempre salvaguardando os princípios fundamentais do Estado de Direito vigente, evitando contradições de valorações indesejáveis ou que conduzam a efeitos gravosos em outros domínios. A compreensão da jurisprudência deve suceder de modo reflexivo, mediante o interpretar, cabendo ao intérprete questionar o texto, examinando a situação que deu origem àquele, e observando outras circunstâncias hermenêuticas, tudo para definir, dentre as interpretações possíveis, a mais correta, que não deve se ater ao sentido isolado de cada palavra, mas o de uma sequência de palavras e frases que expressam um contínuo nexo de ideias. A tarefa do intérprete em tomar como perspectiva prévia o sentido da frase por ele esperado e o sentido do texto no seu conjunto é denominado "círculo hermenêutico", devendo aquele retroceder ao significado da palavra primeiramente aceita e, conforme o caso, retificar-se este ou sua ulterior compreensão, resultando numa concordância sem falhas. As normas jurídicas são interpretadas para serem aplicadas a casos concretos e o problema fundamental é a distância entre a generalidade da norma e a singularidade de cada caso concreto. Fazer tal mediação é a tarefa de concretização da norma. Decerto que as interpretações anteriores não são vinculantes para o juiz, que pode abandoná-las se a interpretação vier a revelar-se insustentável ao retornar à própria norma, ao seu conteúdo significativo e às peculiaridades do caso presente. Compreender uma norma jurídica, nas palavras do autor, "é desvendar a valoração nela imposta e seu alcance”. Por isto, a Jurisprudência é tanto no domínio prático como no domínio teórico um pensamento orientado a valores, havendo a necessidade de aplicação deste pensamento quando a lei recorre a uma pauta de valoração que carece de preenchimento valorativo para definir uma hipótese legal ou também uma consequência jurídica, como nos exemplos "boa-fé”, "justa causa”, entre outros (op. cit., ps. 164/172).
\end{abstract}


Revista Eletrônica de Direito Processual - REDP.

Rio de Janeiro. Ano 13. Volume 20. Número 1. Janeiro a Abril de 2019

Periódico Quadrimestral da Pós-Graduação Stricto Sensu em Direito Processual da UERJ

Patrono: José Carlos Barbosa Moreira (in mem.). ISSN 1982-7636. pp. 288-314

www.redp.uerj.br

que sustentava que sobre valores não seria possível qualquer conhecimento científico. Nesse cenário, a missão contramajoritária do Judiciário se vê seriamente comprometida, especialmente em sede de jurisdição criminal.

\section{Tendências para o Sistema Criminal no Início do Século XXI no Brasil}

São múltiplas as possibilidades de diagnosticar a crise geral e porque está passando a humanidade e muitos são os seus fatores. Sem pretender descrever exaustivamente tais possibilidades e fatores, tampouco esgotar o tema - até porque seria tarefa impossível de ser realizada, é possível apontar algumas causas e consequências desse estado de coisas, à luz do momento presente.

Talvez o grande marco para a instauração desse estado de crise, seja a crise paradigmática a que se referiu Maria Rita Kehl"69: "Em princípio, eu situaria essa crise ética em duas vertentes principais: uma diz respeito ao reconhecimento da lei, outra à desmoralização do código”. Em seguida, a autora explica que está se referindo, não à letra das leis impressas, mas à lei universal que funda nossa condição de seres da cultura e impõe uma renúncia ao excesso de gozo. Gozo, no texto, significa prazer, a busca desmedida pela satisfação de prazer por meio do consumismo de produtos supérfluos, que é incentivado pela nova ordem global neoliberal. Quanto à demoralização do código, ela explica que se refere ao código burguês, que submetia a outras classes sociais valores e ideias da burguesia, como se fossem valores e ideais de todos.

Um outro fator a apontar, já referido acima, talvez seja o neoliberalismo e sua demanda por aumento dos lucros das empresas e por diminuição do estado, e sua proposta de corroer o estado-providência. Para Waquant ${ }^{70}$, trata-se de um projeto político transnacional que enfatiza um arranjo de políticas favoráveis ao mercado, tais como a desregulamentação do trabalho, a mobilidade do capital, a privatização, a agenda monetarista da deflação e autonomia financeira, a liberalização do comércio, concorrência entre zonas e a redução da taxação e dos gastos públicos.

\footnotetext{
${ }^{69}$ Sobre Ética e Psicanálise, $2^{\text {a }}$ reimpressão, São Paulo:Companhia das Letras, 2005, pgs. 13/18.

${ }^{70}$ Forjando o estado neoliberal: trabalho social, regime prisional e insegurança social. Tradução de Sérgio Lamarão, in BATISTA, Vera Malaguti (org). Löis Wacquant e a Questão Penal no Capitalismo Neoliberal. Rio de Janeiro: Revan, 2012. p. 31.
} 
Revista Eletrônica de Direito Processual - REDP.

Rio de Janeiro. Ano 13. Volume 20. Número 1. Janeiro a Abril de 2019

Periódico Quadrimestral da Pós-Graduação Stricto Sensu em Direito Processual da UERJ

Patrono: José Carlos Barbosa Moreira (in mem.). ISSN 1982-7636. pp. 288-314

www.redp.uerj.br

A crise paradigmática, com o declínio do código burguês, aliado ao

consumismo exacerbado e ao neoliberalismo, provocam uma verdadeira explosão de demandas das classes sociais que não têm acesso aos bens de consumo. Por outro lado, as demandas sociais, às quais se dedicava o estado-providência, em franco declínio, leva à explosão de insatisfação social.

Essas explosões sociais geram insegurança social, especialmente por parte das classes sociais beneficiadas pelo status quo, que pressiona por mais segurança, por intervenções legislativas que visam ao direito penal máximo e por um processo penal mais eficiente em termos de investigação e de condenação. Para atingir tais objetivos, dota-se o aparelho estatal de métodos de investigação que ocorrem fora do processo, fora do devido processo legal, apelando-se, muitas vezes, à notoriedade do fato, para, com isso, legitimar prisões cautelares e um processo penal premial, com renúncia a garantias constitucionais.

$\mathrm{O}$ que se constata com isso é o incremento generalizado, no Brasil ${ }^{71}$ e em muitos outros países, do encarceramento como política pública. Nesse ponto, convém lembrar Waquant: "precisamos teorizar a prisão como órgão central do estado"

\section{Conclusão}

Em conclusão, pode-se dizer que cada época marca um modelo processual e de atuação da justiça criminal, adotando-se, sucessivamente: o simbolismo místico; o modelo adversarial com abdicação da gestão da prova e maior democraticidade; o sistema inquisitivo para impor ordem e disciplina; novamente o simbolismo místico com a função de assegurar a regularidade formal da atividade probatória somente; novamente o sistema inquisitivo e a demanda por ordem e disciplina; a racionalidade antropocêntrica e democraticidade; o positivismo e sua ordem; a democraticidade do pós guerra com um

\footnotetext{
71 A Agência Brasil divulgou, em 8/12/2017, a seguinte matéria: O total de pessoas encarceradas no Brasil chegou a 726.712 em junho de 2016. Em dezembro de 2014, era de 622.202. Houve um crescimento de mais de 104 mil pessoas. Cerca de 40\% são presos provisórios, ou seja, ainda não possuem condenação judicial. Mais da metade dessa população é de jovens de 18 a 29 anos e 64\% são negros. Os dados são do Levantamento Nacional de Informações Penitenciárias (Infopen) divulgado hoje (8), em Brasília, pelo Departamento Penitenciário Nacional (Depen), do Ministério da Justiça (http://agenciabrasil.ebc.com.br/geral/noticia/201712/populacao-carceraria-do-brasil-sobe-de-622202-para-726712-pessoas, consulta em 30/1/2018).

72 Op. cit., p. 11-43
} 
Revista Eletrônica de Direito Processual - REDP.

Rio de Janeiro. Ano 13. Volume 20. Número 1. Janeiro a Abril de 2019

Periódico Quadrimestral da Pós-Graduação Stricto Sensu em Direito Processual da UERJ

Patrono: José Carlos Barbosa Moreira (in mem.). ISSN 1982-7636. pp. 288-314 www.redp.uerj.br

modelo garantista e respeito aos direitos humanos; finalmente, nova demanda por ordem e disciplina.

O que se constata com clareza é que a maior demanda por segurança, ordem e disciplina é cíclica e quando atinge grande envergadura, em determinada sociedade, acarreta maior risco à democraticidade e aos princípios do processo penal democrático.

O momento atual em muitos países e especialmente no Brasil é de perda de democraticidade processual e fragilização de garantias.

A pergunta que se deve fazer é se será preciso mais guerras e mortes, mais encarceramento, mais desumanidade, para chegar-se a uma nova fase de pós-guerra para reconhecer o valor da democraticidade, dos direitos humanos e do processo penal democrático?

\section{REFERÊNCIAS BIBLIOGRÁFICAS:}

BATISTA, Nilo e KOSOVSKI, Ester (org). Tributo a Louk Hulsman. Rio de Janeiro: Ed. Revan, 2012.

BATISTA, Vera Malaguti. Introdução Crítica à Criminologia Brasileira. Rio de Janeiro: Ed. Revan, 2011.

BÜLOW, Oskar von. Teoria das Exceções e dos Pressupostos Processuais. Tradução de Ricardo Rodrigues Gama, a partir da edição espanhola. 2 ed. Campinas: LZN Editora, 2005.

CANARIS, Claus-Wilhem. Pensamento Sistemático e Conceito de Sistema na Ciência do Direito. 3 ed. Lisboa: Fundação Calouste Gulbenkian, 2002.

CAPRA, Fritjof - O Ponto de Mutação. São Paulo: Ed. Cultrix, 2006.

COUTINHO, Jacinto Nelson de Miranda O Papel do Novo Juiz no Processo Penal, p. 3-55, in COUTINHO, Jacinto Nelson de Miranda. Crítica à Teoria Geral do Direito Processual Penal. Rio de Janeiro: Renovar, 2001.

CORDERO, Franco. Guida alla Procedura Penale. Turim: Unione Tipografico Editrice Torinese, 1986.

DUSO, Giuseppe. El Poder - Para uma História de La Filosofia Política Moderna. Cidade do México: Siglo Veintiuno Editores, 2005. 
Revista Eletrônica de Direito Processual - REDP.

Rio de Janeiro. Ano 13. Volume 20. Número 1. Janeiro a Abril de 2019

Periódico Quadrimestral da Pós-Graduação Stricto Sensu em Direito Processual da UERJ

Patrono: José Carlos Barbosa Moreira (in mem.). ISSN 1982-7636. pp. 288-314

www.redp.uerj.br

DUSSEL, Enrique. Política de La Liberación - História Mundial e Crítica. Madri: Editorial Trotta, 2007.

DWORKIN, Ronald - La Justicia con Toga. Madri: Ed. Marcial Pons, 2007.

FERRAJOLI, Luigi. Direito e Razão: Teoria do Garantismo Penal. Tradução de Ana Paula Zomer, Fauzi Hassan Choukr, Juarez Tavares e Luiz Flávio Gomes. São Paulo: Revista dos Tribunais, 2002.

FOUCAULT, Michel. Microfísica do Poder. 8 ed. Rio de Janeiro: Ed. Graal, 1989.

GARAPON, Antoine. Bem Julgar - Ensaio sobre o Ritual Judiciário. Lisboa: Instituto Piaget.

GROSSI, Paolo. Mitologias Jurídicas da Modernidade. Florianopolis: Fundação Boiteaux, 2004.

HEGEL, Georg Wilhem Friedrich. Princípios da Filosofia do Direito. Lisboa: Guimarães e Cia Editores, $2^{\text {a }}$ edição, 1976.

HUSSERL, Edmund. A Crise das Ciências Europeias e a Fenomenologia Transcendental Uma Introdução à Filosofia Fenomenológica. Tradução de Pedro Alves da edição alemã de 1962. Rio de Janeiro: Forense Universitária, 2015.

JAKOBS, Günther, e MELIÁ, Manuel Cancio. Direito Penal do Inimigo - Noções e Críticas. 3 ed. Porto Alegre: Livraria do Advogado, 2008.

KELSEN - Teoria Pura do Direito, tradução de João Batista Machado. Coimbra: Armênio Amado Editora, 6 ${ }^{a}$ edição, 1984.

KEHL, Maria Rita. Sobre Ética e Psicanálise, $2^{\text {a }}$ reimpressão, São Paulo:Companhia das Letras, 2005.

LARENZ, Karl. Metodologia da Ciência do Direito. Tradução de José Lamego. Lisboa: Fundação Calouste Gulbenkian, $3^{\text {a }}$ edição, 1997.

LOCKE, John. Segundo Tratado sobre o Governo Civil, disponível em http://www.xr.pro.br/IF/LOCKE-Segundo_tratado_Sobre_O_Governo.pdf, acesso em 16 junho 2016.

MALAN, Diogo. Direito ao Confronto no Processo Penal. Rio de Janeiro: Lumen Juris, 2009.

MARAFIOTI, Luca - Caleidoscopio dello Storico ed Occhili del Processualpenalista, in Rivista di Diritto Processuale, p. 365-374).

MARÍAS, Julian. História da Filosofia. São Paulo: Martins Fontes, 2004. 
Revista Eletrônica de Direito Processual - REDP.

Rio de Janeiro. Ano 13. Volume 20. Número 1. Janeiro a Abril de 2019

Periódico Quadrimestral da Pós-Graduação Stricto Sensu em Direito Processual da UERJ

Patrono: José Carlos Barbosa Moreira (in mem.). ISSN 1982-7636. pp. 288-314 www.redp.uerj.br

PUGLIESE, Giovanni. As Garantias do Acusado na História do Processo Penal Romano, in TUCCI, José Rogério Cruz e. Contribuição ao Estudo Histórico do Direito Processual Penal. 1 ed. Rio de Janeiro: Forense, 1983. p. 43-65.

PAGANO, Francesco Mario. Considerazioni sul Processo Criminale. Bolonha: Società Editrice Il Molino, 2010.

SANTO ANSELMO. Monológio, Os Pensadores, São Paulo: Abril Cultural, SP.

SANTOS, Boaventura de Souza. A Crítica da Razão Indolente: Contra o Desperdício da Experiência. 8 ed. São Paulo: Editora Cortez, 2011. v.1.

SANTOS, Boaventura de Souza. Crítica da Razão Indolente - Contra o Desperdício da Experiência, $1^{\text {o }}$ volume, São Paulo: Cortez Editora, 2011.

SCATTOLA, Merio - El Poder - Para uma História de La Filosofia Política Moderna, org. DUSO, Giuseppe, Siglo Veintiuno Editores, 2005, México.

SIAGURA, Anna Maria. La Negoziabilità della Pena. Milão: Wolters Kluwer/CEDAM, 2015.

TUCCI, José Rogério Cruz e. Contribuição ao Estudo Histórico do Direito Processual Penal. 1 ed. Rio de Janeiro: Forense, 1983.

WAQUANT, Löic. Forjando o estado neoliberal: trabalho social, regime prisional e insegurança social. Tradução de Sérgio Lamarão, in BATISTA, Vera Malaguti (org). Löis Wacquant e a Questão Penal no Capitalismo Neoliberal. Rio de Janeiro: Revan, 2012.

Punir os Pobres: A Nova Gestão da Miséria nos Estados Unidos. Rio de Janeiro: Revan, 2003. 